\title{
Presenting an Image of Thought in Flux
}

\author{
HAMISH MORGAN
}

I remember lots of things about living in an Aboriginal community; hundreds of images, voices and feelings make a pastiche of such experience. If I focus on a single image I am always enchanted by the images that follow, these images released and thrown into movement by one moment of stationary thought. Memories slowing down, speeding away, through their difference and repetition. Most especially I remember first meeting the Ululla mob, but, oddly enough other memories must be described to get you there, and to convey a certain context, feeling, a certain freedom to what I am trying to say. I remember very strongly driving to Ululla, from Meekatharra. I was following Don Miller who had met me at a roadhouse in the morning. I am smiling now writing this; I'm excited like I was at the time, and as I am now. But I must go further back, or more precisely much further forward, way past the opening scene, in order to tell you of Don, give him some shape to give form to these thoughts. These thoughts I have, and hope to convey to you, in order for you to glimpse or sense some of what I feel and know, or at least what I feel I know. It's a case of going forward to go back to present this to you, to me. In fact, and this must be getting tedious, I must go back, to before I was ever at Ululla to tell you something of Don.

But now to some events we can rely upon and understand without blinking and tedium. About fifteen years ago Don bought the lease to 'Ululla', a 300,000-acre sheep station. It was 
actually an 'outstation' of a much larger sheep station, Albion Downs. This means little except the fact that it was relatively cheap, and had very basic and rundown facilities, despite having a huge and quite magnificent shearing shed, which had been the old open-air dance hall in Wiluna back in the gold boom of the 1930s. The hall had been dismantled and transported to Ululla sometime in the 1950s during the wool boom, and put back together again in order to give form and structure to a different event and drama.

There are so many 'facts' to present to give form to Don and Ululla, they are boring to write about, I have nothing to add to them, but they seem necessary in order to anchor my readers to certain conventions of form and sense. And of course, it's completely sensible that a forty-yearold man from Melbourne would buy a sheep station in Western Australia with the idea of setting up an Aboriginal community! This event. Which event? The signing of the lease papers? The handshake, but with whom (it is a lease with the government)? Don's first night by himself with unimaginable thoughts, fears, hopes for the future? The first time the 'Ululla mob' came to Ululla, although of course they weren't called this at the time and have never presented themselves as a defined group? Or perhaps the inaugural event is the first shearing? When did Ululla, this sheep station/Aboriginal community come into existence? When did this Ululla become the Ululla of my memories, this Ululla which I feel I know? Perhaps only now in this non-event of writing and imagination, in this absence of any suitable or reliable presence. This non-presence to myself as I present these thoughts to you. Like Derrida's, Searle's or Sarl's shopping list, perhaps this is just a scribbled note to my failing memory; a not-so-well-thought out memoir, a writing where the presence of sender to receiver cannot be guaranteed.

People started coming to Ululla, no matter when or how it began. It seems absurd to represent Ululla as a thing, as an 'it', when it (see I can't get away from it) exists only for me now as a memory, a memorial and memoir to myself-and maybe to it? Perhaps it is the surety of these remembrances that defines my place in the topology of Ululla. I will my place and my fact of existence there through these memories, and that is something to hold on to, to grasp and cherish like an object, this precious fetish of memory. It's, after all, all that I have, all that I know about Ululla. But it exists in so many ways. Ululla is far beyond what I experienced, what I remember and represent. It's much more than I can imagine, least of all because it doesn't exist as a thing, perhaps more as a movement of bodies through time and space. But this is hard to conceptualise in the beginning, and how would you represent it? And in the end, and after all, all I'm left with are these things I feel I know about Ululla, this actual memory-event, memory's event, the event of memory, that I'm willing to represent. 
So I'm driving to Ululla, it's about two and a half hours from Meekatharra, I'm following Don's truck, or more particularly the dust storm that cyclones behind him. I can smell the dust as I write this, feel the road's bumps, the sway of my car. The road is wet in parts, and every now and again we come across huge puddles in the road, we slow down and churn through the mud. The country must have looked great, it always looked great after rain. But this is something I came to appreciate much later on, once I had a more intimate understanding, a keener set of eyes to focus on the delicate manifestations of semidesert flora. I remember stopping on the side of the road. The place we stopped at was halfway between Meekathara and Ululla, a place we would often stop at on future journeys, though of course I didn't know that then.

Don had some lunch, which he shared with me. He offered me a cup of coffee, it was warm and weak, so much so that it startled me, but that's how he had it. 'It was so weak it was helpless', but that was something my grandfather used to say, or so my Dad recalls, that I recalled both then and now, once uttered out aloud but never spoken by me at that moment. Someone else's statement recalled; a startling reflex that takes me off, then and now, to other places, to other voices. And now anytime I have warm and weak coffee it reminds me of Don. And now because of writing this I am reminded that the relationship between signifier and signified is never guaranteed, is arbitrary, makes no implicit sense just like a cup of coffee standing in for Don, his place in my memory reaffirmed, produced, called to action by a thousand imperfect signifiers, signifiers that take one away towards others. A strange non-event this warm cup of coffee.

Where we had stopped was the flat, smooth space before the abrupt rim of a plateau. Where we had stopped was the top of a 'breakaway' or a 'jump up', which the road went directly over. 'Breakaway' country is where a rock strata forms a band, interrupts a line, unsettles a plateau in a moment of intensity. It's hard to discern if there are many plateaus or just one plateau. Perhaps the 'breakaways' are the strata that interrupt a vast single plateau, or perhaps they are the intense signifiers of the becoming of a thousand plateaus. It was from this place that Don first showed me Ululla. You get a good view from this intense moment that we were standing on. You can see for miles, and you can see plains and plateaus and other breakaways, joining, dissolving, beginning, ending endlessly to the horizon. It was from here that Don showed me Ululla. He waved his arm at the horizon, gestured to some hills to the south and east, and said 'over there' beyond those hills is Ululla. What could I think, I could only imagine. We got back into the warm milieu of our machinic assemblages and drove on towards Ululla.

I have been a little sidetracked by this break, this event for coffee, on the side of the road halfway between Meekatharra and Ululla. It would seem that I have, by way of a break moved 
beyond and before this present of my first trip to Ululla. So let's, now, get back there to this present.

The overwhelming memory that I have of this first trip is that I wanted the right song to be playing on my cassette player when I rolled into Ululla. Looking back this seems like such an absurd memory. I think it was Gillian Welch playing, and I was wishing that a particular favourite would accompany my arrival to Ululla through some combination of provenance and good management. I can't even remember if my plan happened, and it really doesn't matter now, or it matters for a different reason. But at the time I wanted to commemorate and symbolise, create a cogent link between a favourite tune and an inaugural event. Above all I wanted my arrival to be memorable. I wanted a song to remember it by, to make it special, to symbolise my presence, both in the present of my arrival and for the future memory of it. A kind of soundtrack to my arrival, and an anthem for future melancholy.

But now, I don't even remember which song was playing, or who even was playing. Maybe I turned the cassette player off, too confused by the present and future and past, by event and commemoration. Yet, this overwhelming desire to represent my first arrival is one of the strongest memories I have of first getting to Ululla. The actual remembering has been forgotten. What has been remembered was the desire to make it memorable. The actual event of arrival (the first dog barks as we rolled into Ululla? maybe that imagined glimpse from on top of the 'breakaways' an hour before was my arrival? maybe the turning off of our machines? or maybe once the dogs were silent? when had I arrived?) has been swallowed up by the commemorative and symbolic events that may have never actually taken place. All I remember now is this desire to make it memorable and it is this ritual, both now and then, that overwhelms and consumes any ceremony of arrival.

Another event was memorable, and I remember the act rather than the commemorative desire, and it happened on the first day I arrived. I went over to what I later knew as 'middle camp', or 'Sadie mob's camp', or the 'quarters' (the old shearing quarters), to meet some of the Ululla mob-who don't really exist as a defined group, and I'm not sure who represented them at that point. I remember speaking to Daniel, who'd just got home from a day of fencing. He was standing around a fire drum with a huge enamel mug, the size of a billy, full of tea. And I remember Chris giving me an emu egg. He'd blown out the yoke, so it was hollow. He'd given it to me, I'm sure, to diffuse the obvious awkwardness we all felt. However this gift doesn't represent awkwardness, or a least not entirely because it also represents its diffusion and resolution. And now, what I remember most strongly of this first meeting is awkwardness and its diffusion, commemorated and symbolised by an emu egg. Emu eggs are quite fascinating 
close up. They are speckled both blue and green, not so much bluey-green or greeny-blue but both green and blue depending on which speckle you focus your attention on. It's hard to say what colour they are; they are both at the same time while being only one at the one time. And this speckled memory-event and this writing, both awkward and resolved, neither nor, but both at once.

Colebrook drawing on Deleuze argues that 'thought is not the virtual representation of life-it is part of life's infinite and open becoming'. ${ }^{1}$ To think of these things is not to posit that there is a 'world', an external reality, that is then represented. There is no world external to what we think of it and, with equal force, the world always exceeds what can be thought of it. Deleuze argues that:

There are images, things are themselves images, because images aren't in our brain. The brain's just one image among others. Images are constantly acting and reacting on each-other, producing and consuming. There is no difference at all between images, things and motion. ${ }^{2}$

An imperceptible difference or becoming between image, memory, flow and recall. There is no primary, pure flow that is tainted, copied by perception and sense. There is only ever this circuitous becoming and affect of image and things. As Colebrook states:

Deleuze is not arguing that reality is 'just an image' or is constructed by mind. On the contrary, reality in all its difference and complexity cannot be reduced to the extended images 'we' have formed of it. Nor can the mind be seen as the author or origin of all images. ${ }^{3}$

Thought and perception is this affect and becoming of both image and the world, neither nor but both at once.

To explain this, Deleuze develops the concept of a 'plane of immanence'. The plane of immanence needs to be thought of in opposition to, and to break with, the 'plane of transcendence' in which most western thought is grounded. Essentially Deleuze argues that there is no outside, nothing external, no transcendence outside of being itself. Human being is not opposed, or compared, or reducible, to some transcendent being; we are not poor copies or simulacra of some original pure being; there is no reference point, or transcendental being outside of life. Rather life and being are immanent; being inherently and permanently sustains the world. This, as Colebrook explains, is a 'commitment to one univocal being'. She explains that 'if being is univocal this means that any thought or representation that we have of being is itself an event of being'. ${ }^{4}$ It is because being is expressed that the world, social life, thought and reality is possible-this is being's expression. And there is nothing outside or reducible to being's 
expression. Being's expression infinitely exceeds any one representation and is exceeded by the infinite possibilities of representation, perception and sense that the world makes possible, necessary and likely. This concept of 'the plane of immanence' is central to Deleuze's philosophy. Key to an understanding of the plane of immanence is an understanding of deterritorialisation and reterritorialisation, of the mutual becoming of world and representation, not a distinction, but each becoming the other. The 'parable' of the orchid and the wasp traces this. Deleuze and Guattari write:

How could movements of deterritorialisation and processes of reterritorialisation not be relative, always connected, caught up in one another? The orchid deterritorialises by forming an image, a tracing of the wasp; but the wasp reterritorialises on that image. The wasp is nevertheless deterritorialised, becoming a piece in the orchid's reproductive apparatus. But it reterritorialises the orchid by transporting its pollen ... It could be said that the orchid imitates the wasp, reproducing its image in a signifying fashion (mimesis, mimicry, lure, etc) .... At the same time, something else entirely is going on: not imitation at all but a capture of code, surplus value of code, an increase in valence, a veritable becoming, a becoming-wasp of the orchid and a becoming-orchid of the wasp. Each of these becomings brings about the deterritorialisation of one term and the reterritorialisation of the other; the two becomings interlink and form relays in a circulation of intensities pushing the deterritorialisations ever further. ${ }^{5}$

And perhaps to push these deterritorialisations and this intensity further we better see what happens through an event; to see how things get 'caught up in one another'. Let's say a road trip from Meekatharra to Ululla. The whole trip my mind was encountering sensory information, the smell of red dust, the sway of my body, the road, the car; my eyes were looking for bumps, potholes, places to slow down and speed up. All the while my body, my mind, my car These driving thoughts were free to proliferate over the bumps and rattles and squeaks. I am predicting what is around corners imagining what is over the next hill. Wondering what this country means-how to make sense of it and respond to it in a more meaningful and less mechanical way than by changing the gears and by turning the wheel, by changing speeds and trajectories. I am imagining how I will respond in the future to this country, what it will mean to me, and to others, beyond this present of first encounter. 
And now recalling this first trip from Meeka to Ululla, I have countless other memories that startle me with their force. Like the kangaroo I hit, that jumped into the window of the truck I was driving, the noise, the look of fear that I can still see in the kangaroo's eyes less than a foot from my own, the smashed window splitting light into tiny fragments, the window crumbling, glaring; I peer with cautious squinted eyes-as if that would make seeing easier. I drive accordingly, I limp home. Other memories come upon me, from the side of the road out of view, like where I picked up Shelia mob after they had run out of fuel. Or I think of where we camped at Easter. Or where Chris mob ran out of fuel, and the lasting signifiers of their camp that give other journeys a reminder, a nod of a head, 'a hang on, hang-on, wait, kulo (wait), wait (kulo) ... there', as we hurtle past on other trips, a casting of thought back to that event, the past's future signifiers marked on the side of the road.

But back to the present memory of this first trip. This new country, its sights and smells and opportunities nothing like I have encountered before. Quite endless possibilities of becoming, of imagination for the future, all these relays forming across the country, across my mind. And all the while this present of the road, my body, my mind, my car; my thoughts like the fluffy clouds hovering over and, because of the landscape, casting shadows benignly drifting. There is no pure memory of this first trip that I wish or can represent, only an intensity of deterritorilisation and reterritorialisation, only ever this becoming, this expression that is abroad in the world, and in memory-'where the potential is for what may become'.6 Other memories of other trips of other times affect and displace, disrupt and produce this memory. This memory-event is, by now, or so I am trying to make you think, an encounter. A flow of images and intensities beyond, further on into the future, way past this initial trip, beyond its horizon but released, set into motion, recalled by its terrain. Neither nor but both at once, speckled, flecked with affectivity, this past/present/future of memory set into motion through a life event's recall.

One final image of thought. To give authority and presence to what I'm about to say (it's not then just a memory, but noted down at the time), I quote from a letter I wrote to a friend, written in the first few weeks of my arrival:

Ululla is peaceful, perhaps now captured in the sunny disposition of sleeping dogs, lying in the middle of the road, belly to the sun, gorgeous smile on their happy lips. My first week here was spent among other things, befriending the dogs so that I could move freely and happily around the community, and now I feel content like a dog lying in the sun.

Befriending the dogs was something I'd learnt earlier, five years before I got to Ululla when I lived in Papua New Guinea. I discovered then, that the only way to get to know people was to 
first of all get to know their dogs, so that you can then call upon them unannounced, unexpectedly as is becoming to the fundamentals of friendship and of living in a small community. And I remember, but no notes this time, that the first time I meet the Ululla mob at Sadie mob's camp/middle camp/the quarters, the dogs barked, prefaced and terrorised my arrival, my presence. Scolded at, yelled at, name-called, the dogs came to heel. I felt embarrassed that my presence was so disruptive, that I required so much warning, caution, name-calling. Perhaps this was my arrival at Ululla, the inaugural event that is the occasion for this writing and thinking. This initial awkwardness of presence, if you will remember, was resolved and symbolised in the speckled affectivity of the emu egg, given to me to diffuse, I'm sure, the obvious awkwardness we all felt. This egg, this gift, this present, both awkward and resolved, neither nor, then and now, both at once, the trace of each in either diffusing the disruption of first arrival, the event of presence, the possibility of re-presentation.

I would like to thank Liz Reed and Stephen Pritchard for their advice and thoughts on this piece.

Hamish Morgan is completing a PhD through the Center for Australian Indigenous Studies, Monash University. His thesis is concerned with the problematic of representation/writing and is informed by the work of Derrida and Deleuze. <hmor1@student.monash.edu.au> 